\title{
TERMÉK-AZONOSÍTÁSI PROBLÉMÁK KEZELÉSE IPAR 4.0 TECHNOLÓGIÁK HASZNÁLATÁVAL
}

\author{
Cservenák Ákos \\ tudományos segédmunkatárs, Miskolci Egyetem, Logisztikai Intézet \\ 3515 Miskolc, Miskolc-Egyetemváros, e-mail: cservenak.akos@uni-miskolc.hu
}

\section{Tóth Lajos}

$R \& D$ vezetö, Ten Pao Electronics Hungary Ltd. 3508 Miskolc, Bogáncs utca.4, e-mail: mkt@tenpao.com

\section{Akylbek Umetaliev}

egyetemi tanár, Kyrgyz State Technical University named I. Razzakov, Kyrgyz-German Technical Institute 720044 Bishkek,66 Mir Avenue, Kirgiz Köztársaság, e-mail: akylbek.umetaliev@gmail.com

\section{Bányai Tamás}

egyetemi docens, Miskolci Egyetem, Logisztikai Intézet

3515 Miskolc, Miskolc-Egyetemváros, e-mail: alttamas@uni-miskolc.hu

\section{Illés Béla}

egyetemi tanár, Miskolci Egyetem, Logisztikai Intézet

3515 Miskolc,Miskolc-Egyetemváros, e-mail: altilles@uni-miskolc.hu

\section{Tamás Péter}

intézetigazgató egyetemi docens, Miskolci Egyetem, Logisztikai Intézet

3515 Miskolc, Miskolc-Egyetemváros, e-mail: tamas.peter@uni-miskolc.hu

\begin{abstract}
Absztrakt
Az Ipar 4.0 technológiák nemcsak a gyártási és összeszerelési folyamatok teljesitményét javithatják, hanem a kapcsolódó logisztikai müveletek hatékonyságát is növelhetik. A cikk keretein belül bemutatunk egy rendszert a termékkeveredési problémák azonositására az RFID technológiák segitségével. Elöször az a laboratórium kerül bemutatásra, ahol a technológia alkalmazásra kerül. A rakományegységek épitési felszereléseinek és termékeinek azonositása RFID-cimkék alapján történik. Excelformátumú adatbázis fájlt használtunk a termékek kötési mátrixának tárolásához. Kidolgoztunk egy szoftvert, amely irányitja az ipari IF30 RFID olvasót. Szoftverünk egy termékcsalád-észlelési tesztet is képes késziteni. A cikk kitér még a jövőbeni kutatási irányokra is.
\end{abstract}

Kulcsszavak: RFID, termék-azonositás, termékkeveredési problémák, ipar 4.0

\begin{abstract}
Industry 4.0 technologies can improve not only the performance of manufacturing and assembly processes, but also the efficiency of related logistic operations can be increased. Within the frame of this article a system is shown for identifying product mixing problems using RFID technologies. Firstly, the laboratory is introduced, where the technology is used. The identification of loading unit building equipment and products is based on RFID tags. We used Excel format database file to hold the binding matrix of the products. We have developed a software that controls our industrial IF30 RFID
\end{abstract}


reader. Our software performs a product mix detection test as well. The paper highlights also the future research directions.

Keywords: RFID, product identification, product mixing problems, Industry 4.0

\section{Bevezetés}

A rádiófrekvencia-azonosítás (RFID) története a második világháború idejére vezethető vissza. A brit repülőgépek továbbították a saját azonosítójukat az ellenségbarát érzékelőrendszerhez, amikor a radarjeleket fogadták [1,2]. Azóta a rendszert tovább fejlesztették, mérete kisméretü és optimalizált lett. Manapság az RFID rendszerek alacsony frekvencia (LF), magas frekvencia (HF), ultramagas frekvencia (UHF) és mikrohullámú változatokban kaphatók. Aktív eszközöket fejlesztettek ki az olvasási/írási távolság növelésére. Az RFID technológiát alkalmazzák a logisztika, a kereskedelem, a gyógyszeripar, az állattenyésztés, a szállítás és a szolgáltatóipar területén is. Logisztikai rendszerekben is felhasználható termék azonosítására, nyomon követésére és a termék összetételének meghatározására.

Az RFID technológia elméletét és alkalmazását több mint 70 éve kutatják. Leon Theremin orosz fizikus volt az első személy, aki 1946-ban létrehozta az első RFID-készüléket [3].

A technológiát az ipar és a szolgáltatások különböző területein használják. Az RFID végrehajtása nagy hatással van a logisztikai folyamatok rugalmasságára, minőségére, hatékonyságára és elérhetőségére, mivel az emberi hibák következményei enyhíthetők például az általános rakománykezelö logisztikában [4]. A logisztikai műveletek minőségét az azonosító technológiák alkalmazásával lehet javítani, mivel az információfeldolgozás és az adatbányászat felhőtechnológiák alapján végezhető [5]. Az RFID alkalmazások támogathatják a bonyolult logisztikai és anyagkezelési folyamatokat, és az ütemezési, hozzárendelési és útválasztási problémákat nagyobb hatékonysággal lehet megoldani, különösen heurisztikus és metaheurisztikus megoldások alkalmazásával NP-nehéz problémák esetén [6].

Az RFID technológiák speciális alkalmazási területe az egészségügy, ahol a beteg- és gyógyászati eszközkezelés az Ipar 4.0 technológiákkal és a kapcsolódó logisztikai múveletekkel támogatható, mint például az orvosi logisztikai válogató rendszerek fejlesztése [7-8]. A vezeték nélküli érzékelő rendszerek és az RFID megfigyelő rendszerek a repülötéri logisztikában igazolják ezen technológia fontosságát a biztonság területén [10]. Az RFID technológiákat nemcsak a hagyományos gyártási rendszerek esetében alkalmazzák, hanem hibrid vagy felhő alapú megoldások esetében is alkalmazhatók [10]. Az RFID vezeték nélküli érzékelőhálózatok integrációja támogatja a döntési modelleket és a logisztikai rendszerek müködésének optimalizálását [12]. Érdekes alkalmazások találhatók az oktatás, a logisztika, a személyszállítás [13] vagy az állatok intelligens logisztikai irányítása [14] területén. Az RFIDalapú szekvencia-hibabiztos rendszer bevezetése az autóipar logisztikájához megmutatja ennek a technológiának a minőséggel kapcsolatos folyamatokra gyakorolt hatását, mint például a teljes minőségirányítás, a termékek és a folyamatok minősége [15].

Ebben a cikkben egy olyan rendszert mutatunk be, amely termékkeverési problémák azonosításához került kifejlesztésre az Ipar 4.0 eszközeivel. A kifejlesztett rendszer segítségével ellenőrizhető a terhelés egységnyi összetétele, így felfedhetők a lehetséges termékkeverési problémák.

\section{Problémafelvetés}

A gyakorlatban az egységrakományok ellenőrzése gyakran jelentős emberi erőforrásokat igényel. Ilyen eset lehet például a közbenső mủveleti raktárakban, raktárakban, fogadó területeken tárolt egységrakomány összetételének vizsgálata. A vizsgálat ellenőrzi a tárolt termékek típusát és mennyiségét, 
és kiküszöböli a hibákat (több vagy kevesebb termék, nem megfelelő termék stb.). A cikkben bemutatott rendszert úgy fejlesztettük ki, hogy csökkentsék az egységrakományok kézi szétválasztását és az azt követő ellenőrzési műveleteket.

\section{High-tech Logisztikai Laboratórium bemutatása}

A laboratórium bemutatása a [17] alapján történik meg.

A laboratóriumot a jelenlegi helyére 2018-ban telepítették át az intézetben újonnan kialakított helyére, és a rendszer számos alrendszert örökölt az elöző alrendszerekből. A legtöbb alkotóelem az iparban ma is alkalmazott elemből áll vagy egyedi, igényvezérelten fejlesztett eszközöket használ.

A Logisztikai Intézet High-Tech Logisztikai Laboratóriumának központi része egy integrált anyagmozgató rendszer, amely a következő fő alkotóelemekből áll:

- PLC vezérelt görgős szállítószalag, amely a teljes rendszer magját képezi.

- palettázó állomás.

- egy automatizált tárolórendszer felrakógéppel,

- egy vezető nélküli szállítótargonca (AGV=Automated Guided Vehilce) egészíti ki.

A rendszer központi alkotóeleme a görgős pálya rendszer, amely központi elemként összeköti az anyagmozgató rendszer többi komponensével. A szállítórendszer több további modulból áll, amelyek mind külön elektromos hajtással és vezérléssel rendelkeznek. Az egyenes szakaszok 2-4 méteres görgőspálya modulokból állnak, amelyek pneumatikus müködtetésủ blokklemezekkel forgalomtól függöen képesek megállítani (torlasztani) és indítani, valamint optikai szenzorokkal felszerelve információkat képesek gyüjteni, elsősorban a rajtuk közlekedő árukról. Merőleges irányú mozgatásnál forgatóasztal, vagy átemelő berendezés továbbítja az árut a megfelelő irányba. Ezek az elemek szintén elektropneumatikus elven müködnek, amelynek táplevegő ellátásáról a laboratóriumban elhelyezett ipari kompresszor gondoskodik. A rendszer része ezen elemek mellett még egy pneumatikus munkahengerrel müködtetett ládarögzítő, melynek feladata, hogy rögzítse a ládát, amíg a benne lévő munkadarabokkal emberi munkaerő vagy egy robotkar müveletet végez.

A görgőspályarendszer egy gravitációs tároló állványrendszer köré került kialakításra. Ez utóbbi rendszer egy manuálisan müködtetett magától utántöltésre képes tárolórendszer, ezzel az emberi munkahelyet és munkavégzést lehet reprezentálni egy automatizált rendszeren belül vagy mellett. A magasraktári tárolásra alkalmas polcrendszer egy iparban is használatos polcrendszer mintájára készült egyedi rendszer. Ezek a polcrendszerek az ipari üzemekben 15 métertől is magasabbak lehetnek, viszont az intézetben az alacsony belmagasság miatt más megoldásokat kellett alkalmazni. A polcrendszert egy automatikusan müködtethető felrakógép szolgálja ki, amely egy programban tárolt változók és optikai érzékelők segítségével tudja az állványon lévő egyes tárolóhelyek pontos helyét.

Az előzőekben leírt alrendszerek együttesen és automatikusan müködtethetők egy PLC-alapú vezérlőegységgel, azonban az önálló vezérelhetőség érdekében mindegyik alrendszer el van látva különkülön vezérlőegységgel is. A központi PLC vezérlőegységgel automatikusan és manuálisan is lehet müködtetni a különböző egységeket az érintésérzékeny kijelzőjén keresztül.

A laboratórium részét képezi még egy AGV, amely még rugalmasabb módot kínál az egyes áruk mozgatására. Az AGV egy LIDAR szenzorral van felszerelve, amely egy modern és gyakori helyzetmeghatározási mód az autonóm jármüvek számára. Az AGV egyedisége azonban abban rejlik, hogy fel van szerelve egy kompakt 6 szabadságfokú Mitsubishi robotkarral és rátelepített elektromos megfogóval, ezért a megírt program struktúrája szerint képes manipulálni a szállított dobozokban lévő árut is. Jelenleg az AGV és annak mozgásirányítása egy doktori kutatási téma része, pl. [18]. 
A rendszer részeként lehet még említeni az RFID és vonalkód alapú nyomon követést és termékazonosítást is. Ezen rendszer a görgőspályára érkező, távozó, valamint azon haladó termékeket azonosítja és azok útjait követi rádiófrekvenciás jel segítségével. A cikk további része az alkalmazott RFID technológiát részletezi.

\section{A továbbfejlesztett rendszer elemei}

A Miskolci Egyetem Logisztikai Intézetének laboratóriumában kifejlesztett integrált logisztikai rendszer rendelkezik kézi és rögzített helyzetü RFID olvasóval (1. ábra, bal oldalt), különféle erősítésekkel rendelkező antennákkal (1. ábra, jobb oldalt), és öntapadós, nyomtatható és környezetvédelmi szempontból ellenálló, mủanyag címkékkel (2. ábra).

Négy RF antenna csatlakoztatható az IF30 Intermec UHF RFID olvasóhoz. A készülék általános célú I/O portokkal (GPIO), Ethernet hálózati csatlakozóval és RS232 konfigurációs porttal rendelkezik. Támogatott RFID kommunikációs szabványok: EPCglobal UHF Gen 2, ISO 18000-6b, ISO 18000-6c, Philips 1.19 változat, Fairchild G1. Müködési hőmérsékleti tartománya megfelel az ipari követelményeknek $\left(-20^{\circ} \mathrm{C}-55^{\circ} \mathrm{C}\right)$, frekvenciatartománya pedig 865,869 és $915 \mathrm{MHz}$.
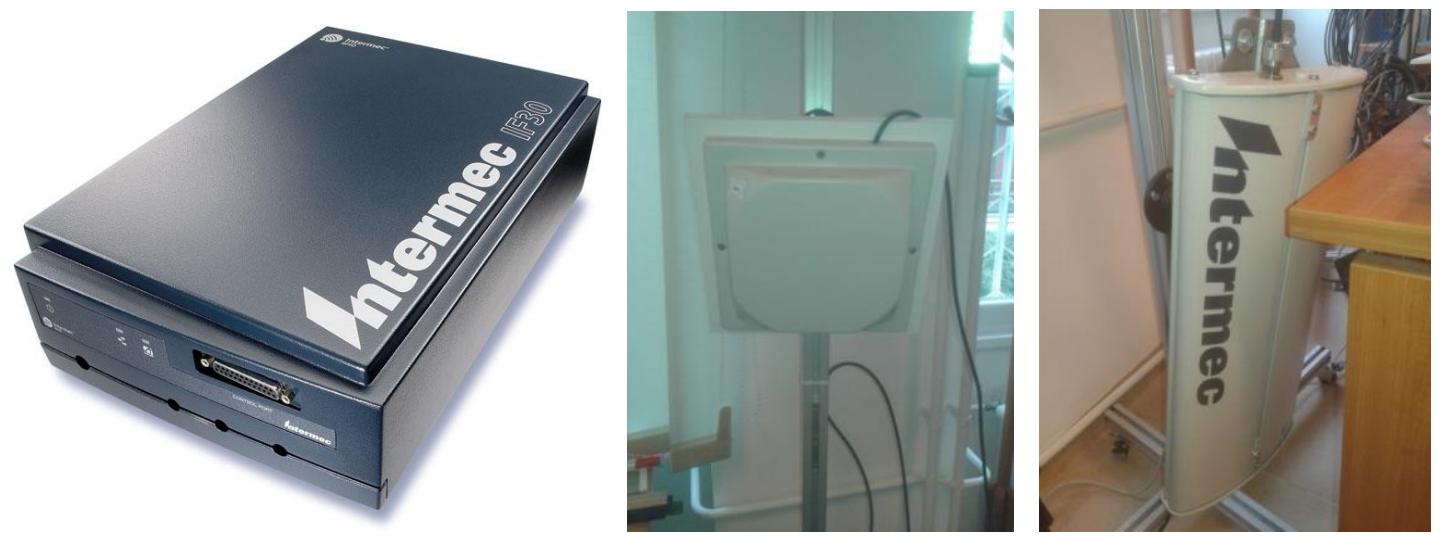

1. ábra. Asztali RFID olvasó és URH antennák

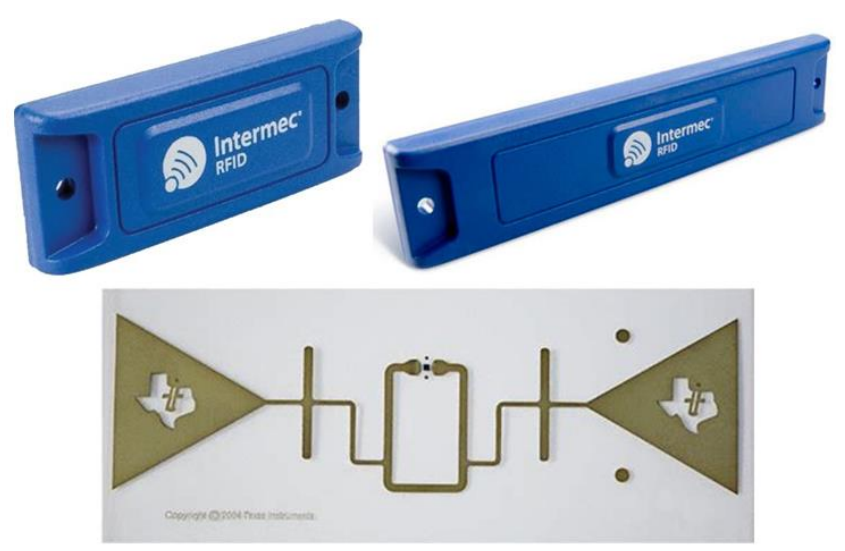

2. ábra. IT65 kis és nagyméretü, passziv RFID tag-ek és Texas Instruments Gen2 címke [16] 
Öntapadós RFID-címkéket ragasztottunk az egységrakományképző eszközökre (ERKE). További, kisebb méretü dobozokat helyeztünk el a nagyobb dobozokba (3. ábra, bal oldalt), amelyek további RFID eszközöket tartalmaznak. Az egyes termékek kapcsolódását rögzítettük egy Excel formátumú adatbázisban (3. ábra, jobb oldalt). Olyan szoftvert fejlesztettünk ki, amely egyrészt irányítja az ipari IF30 RFID olvasóját a termék azonosításához, másrészt a beolvasott azonosítók és az adatbázis alapján egy termékkeverés-észlelési tesztet hajt végre.
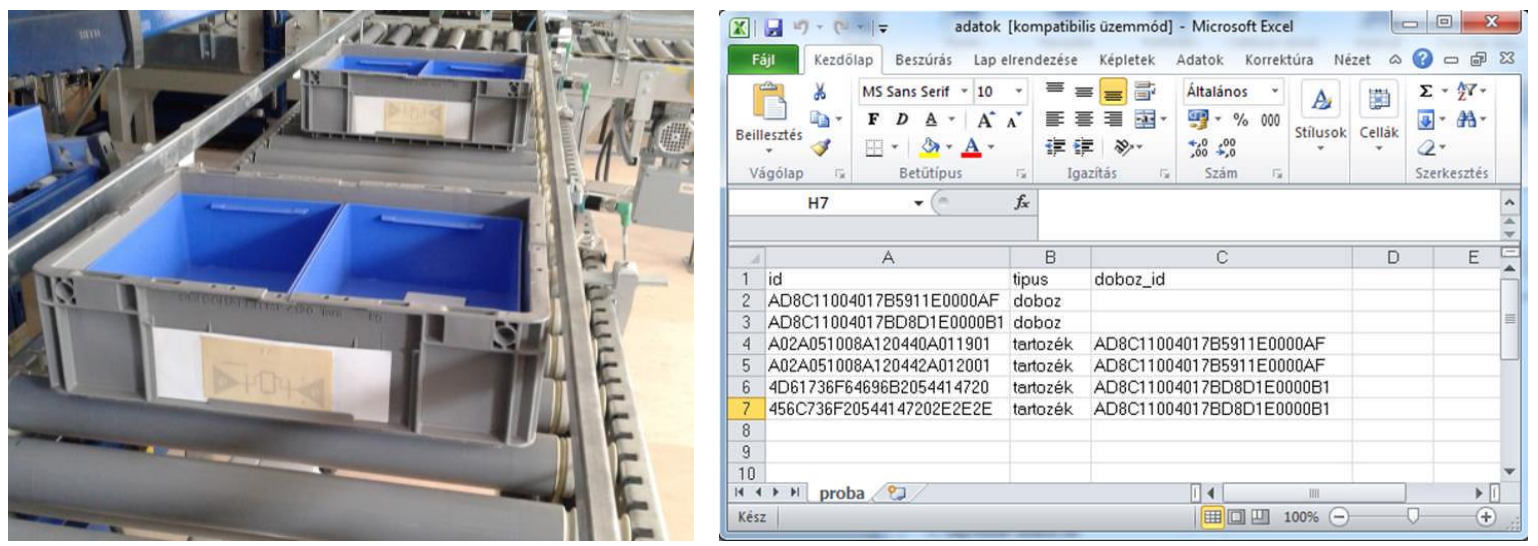

3. ábra. RFID címkével ellátott ERKE és tartozékok, valamint az Excel adatbázis

\section{A továbbfejlesztett rendszer múködése}

A termékazonosítókat adatbázisban kell tárolni. A termék összetételét vizsgáló számítógép az adatbázisban szereplő azonosítókat használhatja annak meghatározására, hogy az egységrakomány megfelelö-e vagy sem. A CSV (Comma-Separated Values = vesszővel elválasztott értékek), Excel vagy MS Access fájl formátum használható adatbázisként. Mi az Excel fájl formátumot használtuk a könnyebb szerkesztéshez.

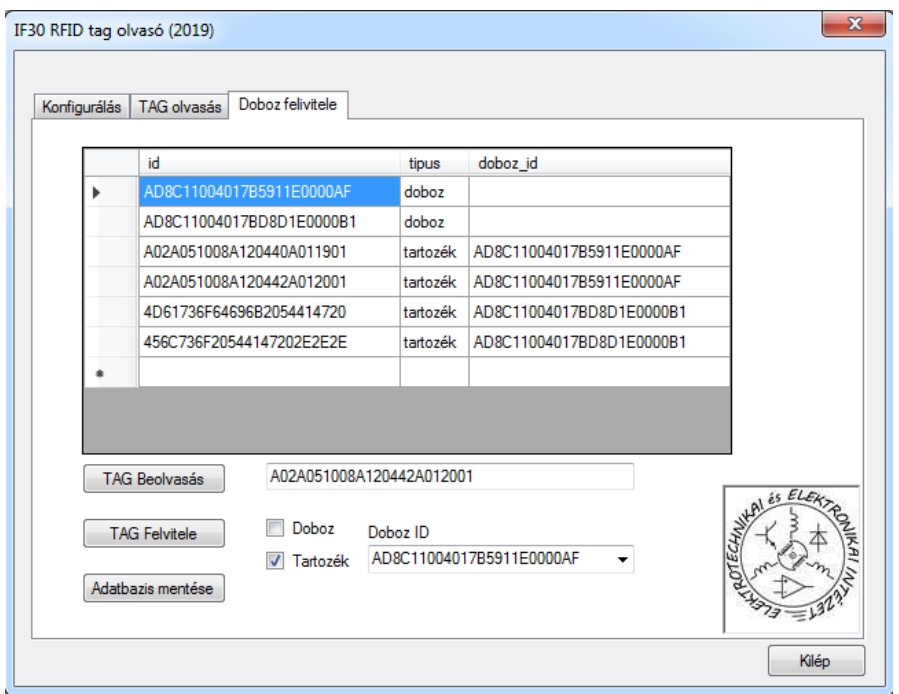

4. ábra. Az alkalmazás adatfelviteli lapja 
Az adatbázisunk jelenleg a termékkapcsolódási mátrixot tartalmazza. Az első oszlop felsorolja az egyes címkék azonosítóit (4. ábra), amelyek egyedi azonosítók. A második oszlop a termékek típusát mutatja. Jelenlegi rendszerünkben az azonosítási típusok két típusát definiáltuk, amelyek lehetnek dobozok vagy tartozékok. Az adatbázis harmadik oszlopában a kiegészítő típusazonosítókhoz meg van adva, hogy melyik dobozhoz tartozik.

A kifejlesztett alkalmazás lehetőséget kínál új adatbázis létrehozására, meglévő adatbázis szerkesztésére és az adatbázis új elemekkel történő kibővítésére. A rendszer müködtetéséhez először be kell konfigurálni az olvasót, így be kell állítani az IF30 hálózati címét, a címkék típusát és a csatlakoztatott antennákat. A konfiguráció helyességét a "Beállítások tesztelése" gomb megnyomásával lehet ellenörizni, amely után visszajelzést kapunk a kapcsolat sikerességéről az alkalmazáskonzolon. Ugyanazon az oldalon (5. ábra) lehetősége van a címke (TAG) olvasásának tesztelésére. A beolvasott címke azonosítója is rá lett nyomtatva a konzolra. A konzol tartalma törölhetö is.

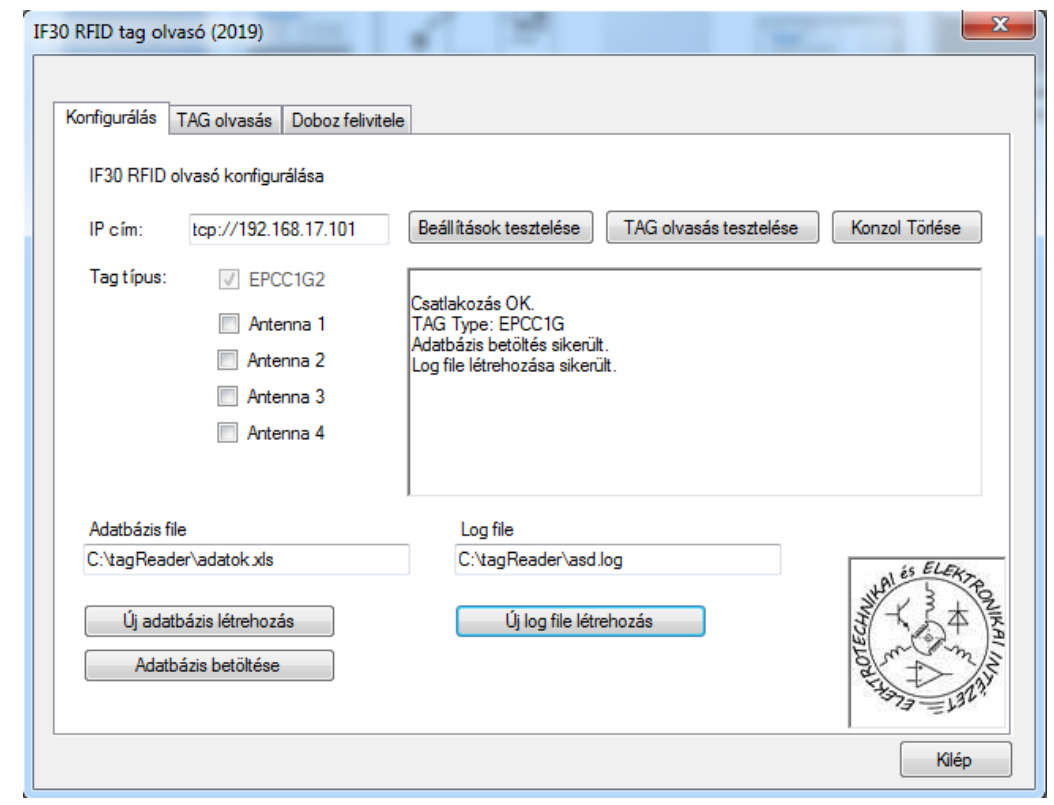

5. ábra. Az alkalmazás konfigurációs lapja

A „TAG olvasás” fülre kattintva elérhető az alkalmazás fő funkciója. A START gombra kattintva a rendszer folyamatosan beolvassa a látókörébe kerülő azonosítókat. Az azonosítók beolvasása után az értékelés automatikusan megtörténik (6. ábra). Három eset lehetséges. Ha a termék összetétele megfelelő: „Minden Megvan!”. Ha valami hiányzik, akkor a hiányzó azonosítók, ha a szükségesnél több termék van benne, akkor a felesleges azonosítók jelennek meg. Az alkalmazás naplózza az időbélyeggel ellátott eseményeket egy naplófájlba, amelyet az adatbázis nevéből hozza létre a későbbi feldolgozás érdekében. 


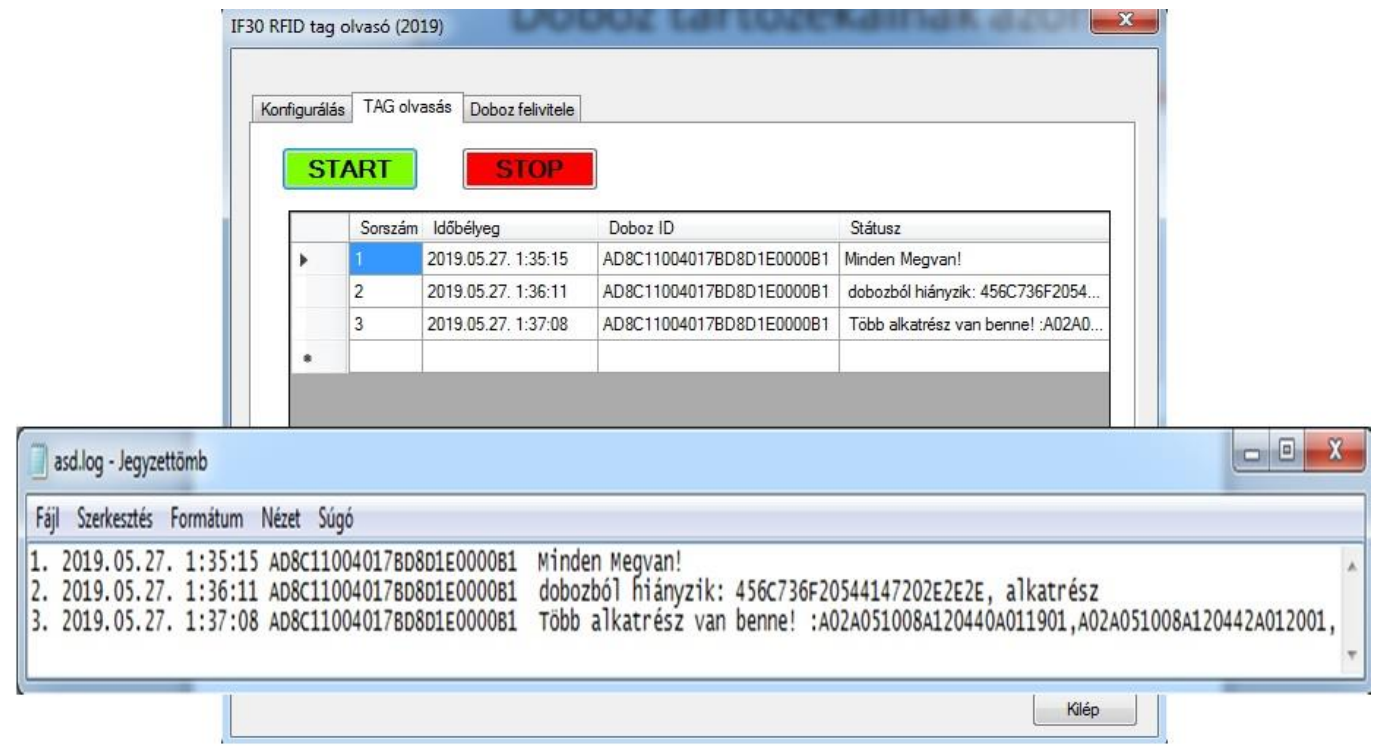

\section{6. ábra. Termékkeveredési problémák kimutatására fejlesztett szoftver}

Az RFID technológia alkalmazási lehetőségei között lehetne említeni oktatási és kutatási célokat is. Az oktatásban a hallgatók számára meg lehetne mutatni egy ilyen rendszer összeállítását, betanítását, programozását és egy konkrét termék azonosításának és nyomon követésének megvalósítását. Kutatások során fel lehetne tárni jelenleg még nem azonosított vagy nyomon követett termékek bevonását is. Valamint a nyomon követés rendszerbe történő integrálása is kutatási célként fogalmazódott meg.

\section{Jövőbeni kutatási irányok}

Egy lehetséges jövőbeli kutatási irányként az RFID technológiát szeretnénk felhasználni laboratóriumunk integrálására és kiber-fizikai logisztikai környezetre történő átalakítására, ahol áruház, raktárak, válogató és szállítórendszer, mobil robot, virtuális valóság modul és intelligens hulladékgyüjtő edény lenne integrálva és IoT (Internet of Things = dolgok internete) megoldásként lenne használva (7. ábra).

A számítási folyamatok felhö-, köd- vagy peremszámításként valósíthatók meg, és a felhasználók a felhőben vagy egy internetes jelentési alkalmazáson keresztül elérhetik az egész rendszert. A rendszer jövőbeli „big data” problémáinak megoldása érdekében a rendszer tervezésével és optimalizálásával kapcsolatos számítási müveleteket egy szuperszámítógéppel lehet elvégezni.

A Logisztikai Intézetben található még egy VR+AR laboratórium is, ahol folyamatszimulációt valósághübb körülmények között lehet megtervezni. Az Intézetben szintén folyamatban különbözö SmartBin-ek fejlesztése, ezek közül egy kisebb méretü már kialakításra is került [19]. A mobil robotok vagy AGV-k kutatása szintén folyamatban van, ahogyan a 3. fejezet megemlítette. A konvejor rendszer már rendelkezésre áll, azonban ennek hatékony RFID technológiával való kiegészítése még további kutatások részét képezi. Mindegyik eszköz az internetre való csatlakozással egyben a felhőalapú technológiákat is igénybe tudja venni. A teljes rendszer vagy egyes alrendszerek irányítása egy web-applikáció vagy felhasználói felület segítségével történhet meg a jövőben. 


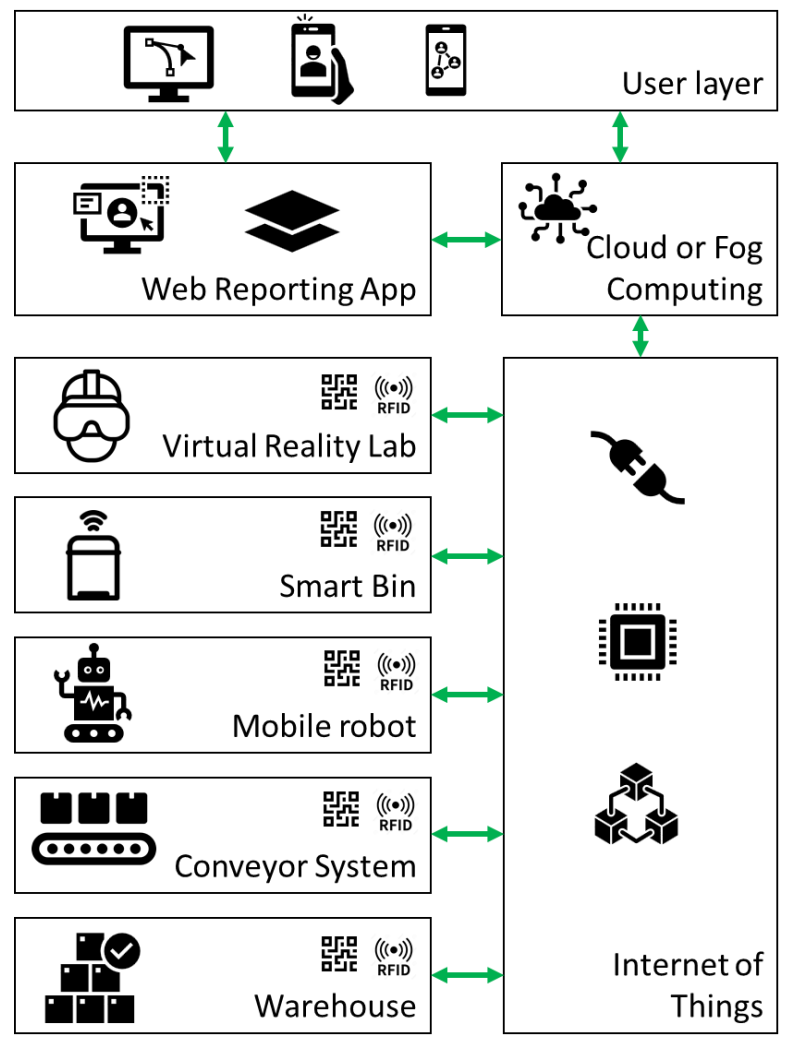

7. ábra. A szokásos logisztikai környezet átalakitása a kiber-fizikai rendszerbe

\section{7. Összefoglalás}

Ezen cikkben részletesen bemutattuk egy termékkeverési problémák azonosítására kifejlesztett rendszert az RFID technológia segítségével. A cikk először felvetette a probléma hátterét, majd ismertette azt a laboratóriumot, ahol az RFID technológia alkalmazásra került. A cikk következő része a továbbfejlesztett rendszert mutatja be, melynek első lépéseként öntapadós RFID-címkéket helyeztünk el az egységrakomány képző egységekre. Ezt követően a többlépcsős egységrakomány kialakítást további RFID-címkékkel hajtottuk végre. Az egyes termékek kapcsolódását Excel formátumú adatbázisba rögzítettük. Olyan szoftvert fejlesztettünk ki, amely egyrészt irányítja az ipari IF30 RFID olvasót a termék azonosításához, másrészt a beolvasott azonosítók és az adatbázis alapján egy termékkeverésészlelési tesztet hajt végre. A rendszer folyamatosan olvassa a látókörébe kerülő azonosítókat. A kifejlesztett rendszer képes felismerni a termék megfelelö összetételét és a hiányzó vagy felesleges termékeket tartalmazó egységrakományokat.

\section{Köszönetnyilvánítás}

A cikkben ismertetett kutató munka az Erasmus + ProdLog és az EFOP-3.6.1-16-2016-00011 jelü „Fiatalodó és Megújuló Egyetem - Innovatív Tudásváros - a Miskolci Egyetem intelligens szakosodást szolgáló intézményi fejlesztése" projekt részeként - a Széchenyi 2020 keretében - az Európai Unió támogatásával, az Európai Szociális Alap társfinanszírozásával valósul meg. 


\section{Irodalom}

[1] Tóth, L., Akylbek, U., Cservenák, Á., Bányai, T., Illés, B., Tamás, P.: (2020) Product identification problems using Industry 4.0 technologies, Journal of Production Engineering, 23(1):7174. http://doi.org/10.24867/JPE-2020-01-071

[2] Radio-frequency identification. Forrás: https://en.wikipedia.org/wiki/Radiofrequency_identification.

[3] Nikitin, P., Parks, A., Smith, J. :(2013) RFID-Vox: A Tribute to Leon Theremin. http://doi.org/10.1007/978-1-4419-6166-2_16

[4] Giusti, I., Cepolina, E.M., Cangialosi, E., Aquaro, D., Caroti, G., Piemonte, A.: (2019) Mitigation of human error consequences in general cargo handler logistics: Impact of RFID implementation. Computers and Industrial Engineering 137:106038. http://doi.org/10.1016/j.cie.2019.106038

[5] Cao, X.H., Li, T., Wang, Q. :(2019) RFID-based multi-attribute logistics information processing and anomaly mining in production logistics. International Journal of Production Research 57(17):5453-5466. http://doi.org/10.1080/00207543.2018.1526421

[6] Lam, C.Y., Ip, W.H.: (2019) An integrated logistics routing and scheduling network model with RFID-GPS data for supply chain management. Wireless Personal Communications 1056(3):803-817. http://doi.org/10.1007/s11277-019-06122-6

[7] Aboelmaged, M., Hashem, G.: (2018) RFID application in patient and medical asset operations management: A technology, organizational and environmental (TOE) perspective into key enablers and impediments. International Journal of Medical Informatics 118:58-64. http://doi.org/10.1016/j.ijmedinf.2018.07.009

[8] Zeng, S.X., Xue, R., Chen, J.B.: (2018) Research and design of medical logistics sorting system based on RFID. Basic \& Clinical Pharmacology \& Toxicology 122(2):11.

[9] Moatari-Kazerouni, A., Bendavid, Y.: (2017) Improving logistics processes of surgical instruments: case of RFID technology. Business Process Management Journal 23(2):448-466. http://doi.org/10.1108/BPMJ-06-2016-0127

[10] Wang, L.: (2018) Application of wireless sensor network and RFID monitoring system in airport logistics. International Journal of Online Engineering 14(1):89-103. http://doi.org/10.3991/ijoe.v14i01.8058

[11] Zhong, R.Y., Lan, S.L., Xu, C., Dai, Q.Y., Huang, G.Q.: (2016) Visualization of RFID-enabled shopfloor logistics Big Data in Cloud Manufacturing. International Journal of Advanced Manufacturing Technology 84(1-4):5-16. http://doi.org/10.1007/s00170-015-7702-1

[12] Mejjaouli, S., Babiceanu, R.F.: (2015) RFID-wireless sensor networks integration: Decision models and optimization of logistics systems operations. Journal of Manufacturing Systems 35: 234-245. http://doi.org/10.1016/j.jmsy.2015.02.005

[13] Yan, X.P., Li, J.: (2019) Animal intelligent logistics management based on RFID technology. Revista Cientifica-Facultad de Ciencias Veterinarias 29(6):1772-1780.

[14] Ramirez, J.J.: (2012) Radio frequency identification (RFID) technology for academic, logistics and passenger transport applications. Ingenieria e Investigacion 32(3):58-65. 
[15] Kang, Y.S., Kim, H., Lee, Y.H.: (2018) Implementation of an RFID-based sequencing-errorproofing system for automotive manufacturing logistics. Applied Sciences-Basel 8(1):109. http://doi.org/10.3390/app8010109

[16] Low frequency cards. Source: Low Frequency Cards, http://www.futurlec.com/LF_Cards.shtml

[17] Károly, M., Veres, P., Skapinyecz, R.: (2019) A Miskolci Egyetem Logisztikai Intézetébe telepitett High-Tech Logisztikai Laboratórium bemutatása, Multidiszciplináris tudományok, 9. kötet. 1 sz. pp. 73-80 https://doi.org/10.35925/j.multi.2019.1.10

[18] Cservenák, Á.: (2019) Mobil robot mozgásának vezérlése, Multidiszciplináris tudományok, 9. kötet. 4 sz. pp. 438-443 https://doi.org/10.35925/j.multi.2019.4.45

[19] Cservenák, Á., Bányai, T.: (2020) SmartBin fejlesztése kiber-fizikai hulladékgyüjtési rendszer kialakitásához, Multidiszciplináris tudományok, $10 . \quad$ kötet. 3 sz. pp. 91-95 https://doi.org/10.35925/j.multi.2020.3.10 